\title{
Kinship Terms in Nepali Language and its Morphology
}

\author{
Prajadhip Sinha \\ Assistant professor \\ Department Of Computer Sc. \\ Kohima Science College
}

\author{
Bairab Sarma \\ Research Scholar \\ Assam University \\ Silchar-Assam
}

\author{
Bipul Shyam Purkayastha \\ Professor \\ Assam University \\ Silchar-Assam
}

\begin{abstract}
Kinship relations are blood relations or those relations which are created naturally. Kinship is a method of acknowledging relations and it is a social bond initiated by blood or genetic as well as marriage. Kinship is important in all cultures and in all human interaction. Kinship is important to anthropology because anthropology is the study of human behaviour and human behaviour is variable. According to M.Lamp[12] to understand fully the nature of kinship systems it is necessary to understand what kind of linguistic elements these are, and what kind of linguistic relationships. The kinship terminology of any language is a natural meeting point for the disciplines of anthropology and linguistics [6]. Like other languages of the world, Nepali kinship terms are also common for Nepali Language. Nepali ${ }^{1}$ or Nepalese (नेपाली) is a language in the Indo-Aryan branch of the Indo-European language family. It takes its root from Sanskrit, the classical language of India. This paper explores the area of kinship terms in Nepali language, and its outlines the standard kinship relations, associated set of terms in the language. The formations of such terms are also elaborated with grammatical analysis. Kinship terms form a considerable part of the WordNet in any language because the kinship terms interacts each other with different relational characteristics of WordNet. Nepali is a morphologically rich language and Kinship terms form an important aspect in morphology of Nepali Language. There are many number of morphological studies in Nepali but most of them are descriptive in nature. Morphology of Nepali has not yet been fully analyzed from computational perspective.
\end{abstract}

\section{Keywords}

Kinship,Terminology,WordNet, Morphology, Computational

\section{INTRODUCTION}

Man is social by nature. He establishes many types of relations with a number of persons. The most important of these relationships is known as kinship and it is a method of acknowledging relationship. It is a social bond initiated by genetic or blood ties as well as marriage. Kinship ties are of fundamental importance in every society all over the world. Family is the point of departure for studying kinship. There are basically two types of kinship within a family and they are Affinal kinship and consanguineous kinship. Affinal kinship is based on marriage and most primary affinal relationship is one between a husband and a wife which in its extended form includes parents and siblings of both sides and their spouses and children. Consanguineal kinship based on descent is called consanguineal kinship, commonly known as blood relation. The relation between a child and his parents, between children of the same set of parents, between uncles and nephews/nieces are examples of consanguineous kinship. Like other languages the kinship terms are also common in the

\footnotetext{
${ }^{1} \mathrm{http} / / /$ en.wikipedia.org/wiki/Nepali language
}

Nepali language. Kinship terms form an important aspect in morphology of Language. Nepali is the national language of Nepal. It is also a medium of a uniform, nationwide, educational system, public administration and mass communication. The most recent official census conducted by the government of Nepal in 2001 reports that there are around 20 million Nepali speakers in Nepal, out of which, it is spoken as the mother tongue by 11 million people, and as a lingua franca by others. Nepali or Nepalese (नेपाली) is a language ${ }^{2}$ which takes its root from Sanskrit, the classical language of India. Nepali was previously known as Khas Kura and the language of the Khasa kingdom, which ruled over the foothills of current Nepal during the 13th and 14th centuries. The history of the usage of Nepali in writing dates as back as the 12th century AD. Nepali is written with the Devanagari alphabet, which developed from the Brahmi script in the 11th century AD. Linguistically, Nepali is most closely related to Hindi. A large proportion of the technical vocabulary is shared by Hindi and Nepali. Even the script is more or less the same for both languages and differing with each other in only a few minor details. It is the official language of Nepal and is also spoken in Bhutan, parts of India and parts of Myanmar (Burma) and in India; it is one of the country's 22 official languages ${ }^{3}$ of India.

\section{Nepali Kinship Terms}

We describe the Nepali relations through both consanguinity and affinity. In this case, the consanguinity is the relation by blood or the connection of persons descended from the same stock or common ancestors. Furthermore, the consanguineal relations consist of two types of relation, viz. core and peripheral. On the other hand, the affinal relation is the relation made by marriage but not by blood. The affinal relations also consist of two types, viz. core and peripheral. For convenience, we have followed the common ethnological abbreviations [5] which are : $[\mathrm{P}=$ parents, $\mathrm{M}=$ mother, $\mathrm{F}=$ father, $\mathrm{B}=$ brother; $\mathrm{Z}=$ sister; $\mathrm{S}=$ son; $\mathrm{D}=$ daughter; $\mathrm{H}=$ husband; $\mathrm{W}=$ wife $\mathrm{E}=$ spouse $\mathrm{G}=$ siblings; $\mathrm{C}=$ child e= elder; $y=$ younger]

Consanguineal relations: The kinship relations are made by different ways. One among them is consanguineal relation which is made by blood. It is the relation among the same stock or common ancestors. The consanguineal relations can be classified into two types of relation, namely core and peripheral.

Representing kinship terms of core consanguineal relations: The relations made by the ego directly are the core consanguineal relations. The core consanguineal relations, as

\footnotetext{
${ }^{2} \mathrm{http} / / /$ en.wikipedia.org/wiki/Nepali_language

3 At present there are 22 languages listed under the ES (Eighth Schedule). Three languages, namely Manipuri, Konkani, and Nepali, were included in ES in 1992 through the Seventy-First Amendment
} 
its name suggests are really the core relations and consist of ego's parents, siblings and offspring. For these relations, there are the following kinship terms[2] .

\begin{tabular}{|c|c|c|}
\hline $\begin{array}{c}\text { Kinship } \\
\text { relation }\end{array}$ & $\begin{array}{c}\text { Kinship } \\
\text { terms }\end{array}$ & $\begin{array}{c}\text { Generation } \\
\text { from ego }\end{array}$ \\
\hline $\mathrm{F}$ & Baba & $\mathrm{G}+1$ \\
\hline $\mathrm{M}$ & Amma & $\mathrm{G}+1$ \\
\hline $\mathrm{eB}$ & Daju & $\mathrm{G}=0$ \\
\hline $\mathrm{yB}$ & Bhai & $\mathrm{G}=0$ \\
\hline $\mathrm{eZ}$ & Didi & $\mathrm{G}=0$ \\
\hline $\mathrm{yZ}$ & Buhari & $\mathrm{G}=0$ \\
\hline $\mathrm{C}$ & Nani & $\mathrm{G}-1$ \\
\hline $\mathrm{S}$ & Chhora & $\mathrm{G}-1$ \\
\hline $\mathrm{D}$ & Choori & $\mathrm{G}-1$ \\
\hline
\end{tabular}

TABLE 1-- Representing kinship terms of core consanguineal relations

The core consanguineal relations are father, mother, elder/younger brother, elder/younger sister, child, son and daughter. So there are nine terms for core consanguineal relations in Nepali. There are not sex and age neutral terms in Nepali which are found in English like parents, brother, sister, etc. In Nepali, the terms, viz. daju (eB), Bhai (yB) make the age distinction and the terms, viz. Daju (eB), Didi (eZ) make the sex distinction.

\section{Representing kinship terms of peripheral consanguineal relations}

The peripheral consanguineal relations are not the direct relation of the ego but the ego's relations through the core consanguineal relations are called the peripheral consanguineal relations. It is also called the relations through relations. The peripheral consanguineal relations can be interpreted by a number of relations which are as follows:

\section{Through parents' up generation:}

\begin{tabular}{|c|c|c|}
\hline $\begin{array}{c}\text { Kinship } \\
\text { relation }\end{array}$ & $\begin{array}{c}\text { Kinship } \\
\text { terms }\end{array}$ & $\begin{array}{c}\text { Generation } \\
\text { from ego }\end{array}$ \\
\hline $\begin{array}{c}\text { FFF, FMF, } \\
\text { MFF, MMF }\end{array}$ & Jiju baje & $\mathrm{G}+3$ \\
\hline $\begin{array}{c}\text { FFM, FMM, } \\
\text { MFM, } \\
\text { MMM }\end{array}$ & jiju boju & $\mathrm{G}+3$ \\
\hline FF, MF & baje & $\mathrm{G}+2$ \\
\hline FM, MM & boju & $\mathrm{G}+2$ \\
\hline
\end{tabular}

TABLE 2-- Representing kinship terms through Parents' up generation
The peripheral consanguineal relations made by parents' up generation are father's/mother's father's father, father's/mother's mother's father, father's/mother's father's mother, father's/mother's mother's mother, father's/mother's father, father's/ mother's mother.

\section{Through father:}

\begin{tabular}{|c|c|c|}
\hline Kinship relation & Kinship terms & $\begin{array}{c}\text { Generation } \\
\text { from ego }\end{array}$ \\
\hline $\mathrm{FeB}$ & thula babu & $\mathrm{G}+1$ \\
\hline $\mathrm{FeBW}$ & thuli ama & $\mathrm{G}+1$ \\
\hline $\mathrm{FyB}$ & $\begin{array}{c}\text { kaka/kancha } \\
\text { babu }\end{array}$ & $\mathrm{G}+1$ \\
\hline $\mathrm{FyBW}$ & kaki/kanchhiama & $\mathrm{G}+1$ \\
\hline $\mathrm{FeZ} / \mathrm{FyZ}$ & Phupu & $\mathrm{G}+1$ \\
\hline FZH & Phupaju & $\mathrm{G}+1$ \\
\hline
\end{tabular}

\section{TABLE 3-- Representing kinship terms through father}

The peripheral consanguineal relations through father are father's elder/younger brother, father's elder/younger sister. These terms make a clear age distinction which is dissimilar to English terms uncle for FB and aunt for FZ.

Through mother:

\begin{tabular}{|c|c|c|}
\hline $\begin{array}{c}\text { Kinship } \\
\text { relation }\end{array}$ & $\begin{array}{c}\text { Kinship } \\
\text { terms }\end{array}$ & $\begin{array}{c}\text { Generation } \\
\text { from ego }\end{array}$ \\
\hline $\mathrm{MeB}$ & Mama & $\mathrm{G}+1$ \\
\hline $\mathrm{MyB}$ & Mama & $\mathrm{G}+1$ \\
\hline $\mathrm{MeZ}$ & Thool-ama & $\mathrm{G}+1$ \\
\hline $\mathrm{MyZ}$ & Chema & $\mathrm{G}+1$ \\
\hline
\end{tabular}

\section{TABLE 4-- Representing kinship terms through mother}

In Nepali, there is similar term mama for mother's elder/younger brother (MeB, MyB), which is an age-neutral

Through father's/mother's siblings:

\begin{tabular}{|c|c|c|}
\hline Kinship relation & $\begin{array}{c}\text { Kinship } \\
\text { terms }\end{array}$ & $\begin{array}{c}\text { Generation } \\
\text { from ego }\end{array}$ \\
\hline FBeS, FZeS,MBeS, MZeS & Daju & $\mathrm{G}=0$ \\
\hline FByS, FZyS MByS, MZyS & Bhai & $\mathrm{G}=0$ \\
\hline FBeD, FZeD, MBeD, MZeD & Didi & $\mathrm{G}=0$ \\
\hline FByD, FZyD, MByD, MZyD & bohini & $\mathrm{G}=0$ \\
\hline
\end{tabular}

TABLE 5-- Representing kinship terms through father's/mother's siblings

The peripheral consanguineal relations through father's siblings are father's brother's/sister's elder/younger son and father's brother's/sister's elder/younger daughter. The relations 
made by father's siblings are upholding both age and sex distinction. Elder and younger are distinctly noticed by the like 'daju' and 'bhai' which is dissimilar to the terms found in English like cousin for both sex.

Through male ego:

\begin{tabular}{|c|c|c|}
\hline $\begin{array}{c}\text { Kinship } \\
\text { relation }\end{array}$ & $\begin{array}{c}\text { Kinship } \\
\text { terms }\end{array}$ & $\begin{array}{c}\text { Generation } \\
\text { from ego }\end{array}$ \\
\hline BS & Bhatija & G-1 \\
\hline BD & Bhatiji & G-1 \\
\hline ZS & Bhanja & G-1 \\
\hline ZD & Bhanji & G-1 \\
\hline
\end{tabular}

TABLE 6-- Representing kinship terms through male ego

Through female ego:

\begin{tabular}{|c|c|c|}
\hline $\begin{array}{c}\text { Kinship } \\
\text { relation }\end{array}$ & $\begin{array}{c}\text { Kinship } \\
\text { terms }\end{array}$ & $\begin{array}{c}\text { Generation } \\
\text { from ego }\end{array}$ \\
\hline BS & Bhoda & G-1 \\
\hline BD & Bhodi & G-1 \\
\hline ZS & Chhora & G-1 \\
\hline ZD & Choori & G-1 \\
\hline
\end{tabular}

TABLE 7-- Representing kinship terms through female ego

The peripheral consanguineal relations made by female ego are the same to the relation made by male ego. But the terms are different. The relations, namely brother's/sister's son and brother's/sister's daughter by male ego and female ego are termed differently because of sex distinction.

\section{Through child:}

\begin{tabular}{|c|c|c|}
\hline $\begin{array}{c}\text { Kinship } \\
\text { relation }\end{array}$ & $\begin{array}{c}\text { Kinship } \\
\text { terms }\end{array}$ & $\begin{array}{c}\text { Generation } \\
\text { from ego }\end{array}$ \\
\hline SS, DS & Nati & G-2 \\
\hline SD, DD & Natini & G-2 \\
\hline
\end{tabular}

\section{TABLE 8-- Representing kinship terms through child}

The peripheral consanguineal relations made by child are overlapping. Son's son and daughter's son are called by the same term nati. Similarly, son's daughter and daughter's daughter are also called by the term natini.

\section{Affinal relations}

The relations made by marriage but not by blood are called the affinal relations. In this way, there are two major ways to establish the relations although there are other ways for establishing the relation. Similar to the consanguineal relations, the affinal relations also have two further types. They are core an peripheral which are described below.

\section{Representing kinship terms of core affinal relations}

The concept of the core affinal relation is similar to the core consanguineal relations but they are considerabley different to each other. The affinal relations (made by marriage) through the core consanguineal relations are called the core affinal relations. The core affinal relations are made by the ego's father, mother, siblings and offspring. They are gradually treated in the following ways.

\section{Through father:}

\begin{tabular}{|c|c|c|}
\hline $\begin{array}{c}\text { Kinship } \\
\text { relation }\end{array}$ & $\begin{array}{c}\text { Kinship } \\
\text { terms }\end{array}$ & $\begin{array}{c}\text { Generation } \\
\text { from ego }\end{array}$ \\
\hline FeBW & Thuloama & $\mathrm{G}+1$ \\
\hline FyBW & Kaki & $\mathrm{G}+1$ \\
\hline FeZH & Phupaju & $\mathrm{G}+1$ \\
\hline FyZH & Phupaju & $\mathrm{G}+1$ \\
\hline
\end{tabular}

TABLE 9-- Representing kinship terms through father

The affinal relations made by father are father's elder/younger brother's wife and father's elder/younger sister's husband.

Through mother:

\begin{tabular}{|c|c|c|}
\hline $\begin{array}{c}\text { Kinship } \\
\text { relation }\end{array}$ & $\begin{array}{c}\text { Kinship } \\
\text { terms }\end{array}$ & $\begin{array}{c}\text { Generation } \\
\text { from ego }\end{array}$ \\
\hline $\mathrm{MeBW}$ & Maiju & $\mathrm{G}+1$ \\
\hline $\mathrm{MyBW}$ & Maiju & $\mathrm{G}+1$ \\
\hline $\mathrm{MeZH}$ & Thoolababa & $\mathrm{G}+1$ \\
\hline MyZH & Thoolababa & $\mathrm{G}+1$ \\
\hline
\end{tabular}

\section{TABLE 10-- Representing kinship terms through mother}

The affinal relations through mother are mother's elder/younger brother's wife and mother's elder/younger sister's husband.

Through the ego's siblings:

\begin{tabular}{|c|c|c|}
\hline $\begin{array}{c}\text { Kinship } \\
\text { relation }\end{array}$ & $\begin{array}{c}\text { Kinship } \\
\text { terms }\end{array}$ & $\begin{array}{c}\text { Generation } \\
\text { from ego }\end{array}$ \\
\hline GeBW & Buhari & $\mathrm{G}=0$ \\
\hline GyBW & Bhauju & $\mathrm{G}=0$ \\
\hline GeZH & Bhinaju & $\mathrm{G}=0$ \\
\hline GyZH & Juwai & $\mathrm{G}=0$ \\
\hline
\end{tabular}

TABLE 11-- Representing kinship terms through ego's siblings

The affinal relations through ego's siblings are siblings' elder/younger brother's wife and siblings' elder/younger sister's husband. For these relations, there are four different

Terms in nepali. 
Through the ego's child

\begin{tabular}{|c|c|c|}
\hline $\begin{array}{c}\text { Kinship } \\
\text { relation }\end{array}$ & $\begin{array}{c}\text { Kinship } \\
\text { terms }\end{array}$ & $\begin{array}{c}\text { Generation } \\
\text { from ego }\end{array}$ \\
\hline $\mathrm{SW}$, & buhari & $\mathrm{G}=0-1-2$ \\
$\mathrm{SSW}$, & & \\
$\mathrm{DSW}$ & & \\
\hline $\mathrm{DH}$, & Juwai & $\mathrm{G}=0-1-2$ \\
\hline $\mathrm{DDH}$, & nati & $\mathrm{G}=0-1-2$ \\
$\mathrm{SDH}$ & Juwai & \\
\hline
\end{tabular}

TABLE 12-- Representing kinship terms through ego's child

The terms buhari is common term for SW, SSW, and DSW.

\section{Representing kinship terms of peripheral affinal relations}

The affinal relations through peripheral consanguineal relations are known as the peripheral affinal relations. The peripheral affinal relations are also established through different relations which are treated below.

Through

parents'

siblings:

\begin{tabular}{|c|c|c|}
\hline Kinship relation & $\begin{array}{c}\text { Kinship } \\
\text { terms }\end{array}$ & $\begin{array}{c}\text { Generation } \\
\text { from ego }\end{array}$ \\
\hline PZDeH, PBDeH & Juwai & $\mathrm{G}=0$ \\
\hline PZDyH, PBDyH & Juwai & $\mathrm{G}=0$ \\
\hline PZSeW, PBSeW & Bouji & $\mathrm{G}=0$ \\
\hline PZSyW, PBSyW & Buhari & $\mathrm{G}=0$ \\
\hline
\end{tabular}

TABLE 13-- Representing kinship terms through parents' siblings

The affinal relations through parent's sibling are parent's brother's/sister's elder daughter's husband, parent's brother's/sister's younger daughter's husband, parent's brother's/sister's elder son's wife and parent's brother's/sister's younger son's wife.

Through parents' child:

\begin{tabular}{|c|c|c|}
\hline $\begin{array}{c}\text { Kinship } \\
\text { relation }\end{array}$ & Kinship terms & $\begin{array}{c}\text { Generation from } \\
\text { ego }\end{array}$ \\
\hline SWF, DHF & Samdhi & G-0 \\
\hline SWM, DHM & Samdhini & G-0 \\
\hline
\end{tabular}

TABLE 14-- Representing kinship terms through parents'child

The peripheral affinal relations made by parents' child are son's wife's/daughter's husband's father, son's wife's/daughter's husband's mother. These are cross relations and reciprocal terms.
Through ego's siblings

\begin{tabular}{|c|c|c|}
\hline Kinship relation & $\begin{array}{c}\text { Kinship } \\
\text { terms }\end{array}$ & $\begin{array}{c}\text { Generation } \\
\text { from ego }\end{array}$ \\
\hline BSW & bhatija buhari & G-1 \\
\hline BDH & bhatiji Juwai & G-1 \\
\hline ZSW & bhanja buhari & G-1 \\
\hline ZDH & bhanji Juwai & G-1 \\
\hline
\end{tabular}

TABLE 15-- Representing kinship terms through ego's siblings

The peripheral affinal relations made by ego's siblings are brother's/sister's son's wife and brother's/sister's daughter's husband.

Through ego's wife:

\begin{tabular}{|c|c|c|}
\hline $\begin{array}{c}\text { Kinship } \\
\text { relation }\end{array}$ & $\begin{array}{c}\text { Kinship } \\
\text { terms }\end{array}$ & $\begin{array}{c}\text { Generation } \\
\text { from ego }\end{array}$ \\
\hline $\mathrm{W}$ & Svasni & $\mathrm{G}=0$ \\
\hline $\mathrm{WeB}$ & Jethan & $\mathrm{G}=0$ \\
\hline WeBW & Jethandidi & $\mathrm{G}=0$ \\
\hline WyB & Salo & $\mathrm{G}=0$ \\
\hline WyBW & Bhaini & $\mathrm{G}=0$ \\
\hline WyZ & jethi sasu & $\mathrm{G}=0$ \\
\hline WeZH & Daju & $\mathrm{G}=0$ \\
\hline WyZ & Sali & $\mathrm{G}=0$ \\
\hline WyZH & Sadubhai & $\mathrm{G}=0$ \\
\hline
\end{tabular}

TABLE 16-- Representing kinship terms through ego's wife

These peripheral affinal relations, as mentioned in the table are made by ego's wife perspective. The ego is male and the relations are established through his wife. The relations through wife are wife, wife's elder brother and his wife, wife's younger brother and his wife, wife's elder sister and her husband, wife's younger sister and her husband.

Through ego's husband:

\begin{tabular}{|c|c|c|}
\hline $\begin{array}{c}\text { Kinship } \\
\text { relation }\end{array}$ & $\begin{array}{c}\text { Kinship } \\
\text { terms }\end{array}$ & $\begin{array}{c}\text { Generation } \\
\text { from ego }\end{array}$ \\
\hline $\mathrm{H}$ & Logne & $\mathrm{G}=0$ \\
\hline $\mathrm{HeB}$ & Jethaju & $\mathrm{G}=0$ \\
\hline $\mathrm{HeBW}$ & Jethani & $\mathrm{G}=0$ \\
\hline $\mathrm{HyB}$ & Devar & $\mathrm{G}=0$ \\
\hline $\mathrm{HyBW}$ & Devarani & $\mathrm{G}=0$ \\
\hline $\mathrm{HeZ}$ & Amaju & $\mathrm{G}=0$ \\
\hline
\end{tabular}




\begin{tabular}{|c|c|c|}
\hline HeZH & Buwa & $\mathrm{G}=0$ \\
\hline HyZ & Nanda & $\mathrm{G}=0$ \\
\hline HyZH & Nandebhai & $\mathrm{G}=0$ \\
& & \\
\hline
\end{tabular}

\section{TABLE 17-- Representing kinship terms through ego's husband}

The relations made by ego's husband are more similar to the relations made by ego's wife. But there are different terms for some relations like wife's younger brother (WyB) and husband younger brother (HyB).

Through brother's wife and sister's husband:

\begin{tabular}{|c|c|c|}
\hline $\begin{array}{c}\text { Kinship } \\
\text { relation }\end{array}$ & Kinship terms & $\begin{array}{c}\text { Generation from } \\
\text { ego }\end{array}$ \\
\hline $\mathrm{BWeB}, \mathrm{SHeB}$ & Buwa & G-0 \\
\hline $\mathrm{BWyB}, \mathrm{SHyB}$ & Saiba & $\mathrm{G}-0$ \\
\hline $\mathrm{ZWeB}, \mathrm{ZHeB}$ & buwa & $\mathrm{G}-0$ \\
\hline $\mathrm{ZWyB}, \mathrm{ZHyB}$ & Saiba & $\mathrm{G}-0$ \\
\hline
\end{tabular}

TABLE 18-- Representing kinship terms through brother's wife and sister's husband

The peripheral affinal relations made by brother's wife and sister's husband are brother's wife's/sister's husband's elder/younger brother, sister's wife's/sister's husband's elder/younger brother.

Through his or her spouse:

\begin{tabular}{|c|c|c|}
\hline Kinship relation & $\begin{array}{c}\text { Kinship } \\
\text { terms }\end{array}$ & $\begin{array}{c}\text { Generation } \\
\text { from ego }\end{array}$ \\
\hline EFF, EMF & Bajsosura & $\mathrm{G}+2$ \\
\hline EFM, EMM & Bojusasu & $\mathrm{G}+2$ \\
\hline $\mathrm{EF}$, & Sosura & $\mathrm{G}+1$ \\
\hline $\mathrm{EFeB}$ & thula & $\mathrm{G}+1$ \\
\hline $\mathrm{EFeBW}$ & thuliamasasu & $\mathrm{G}+1$ \\
\hline $\mathrm{EFyB}$ & kanchhasosura & $\mathrm{G}+1$ \\
\hline $\mathrm{EFyBW}$ & kanchhisasu & $\mathrm{G}+1$ \\
\hline $\mathrm{EMyZ/EMeZ}$ & Sanimasasu & $\mathrm{G}+1$ \\
\hline $\mathrm{EMe} / \mathrm{yB}$ & mamasosura & $\mathrm{G}+1$ \\
\hline $\mathrm{EMe} / \mathrm{yBW}$ & Maijusasu & $\mathrm{G}+1$ \\
\hline $\mathrm{EFe} / \mathrm{yZ}$ & Phupusasu & $\mathrm{G}+1$ \\
\hline $\mathrm{EFe} / \mathrm{yZH}$ & phupajusosura & $\mathrm{G}+1$ \\
\hline $\mathrm{EMZe/yH}$, & sanababusora & $\mathrm{G}+1$ \\
\hline $\mathrm{EM}$ & Sasu & $\mathrm{G}+1$ \\
\hline
\end{tabular}

TABLE 19-- Representing kinship terms through his or her spouse

\section{The morphology of Nepali kinship terms}

Morphology (linguistics) ${ }^{4}$ means, the study of the structure and content of word forms. Nowadays morphology is considered an autonomous component on the same footing as syntax and semantics. The term morphology ${ }^{5}$ is Greek and is a makeup of morph- meaning 'shape, form', and -ology which means 'the study of something'. The term is used not only in linguistics but also in biology as the scientific study of forms and structure of animals and plants, and in geology as the study of formation and evolution of rocks and land forms. We are going to stick to morphology in linguistics, as the scientific study of forms and structure of words in a language. The knowledge of morphology is necessary in order to know the way the human brain works and processes language. It will help to produce new alternatives to learn languages and it will permit its application to artificial intelligence.

The words are considered to be fundamental building blocks of language. A word (i.e. word form), in real sense, can either be in simple, complex, compound or reduplicated. A simple word consists of a root or stem together with suffixes or prefixes. A compound term can be broken up into two or more independent terms. Nepali has a number of kinship terms in which female gender is indicated by a final suffix i.e /-i/ or /ni/, such as chorā 'son' versus chorī 'daughter', and is also used to indicate biological sex in non-human animates, such as kukur 'hound' versus kukurnī 'bitch'[7].

Nouns in Nepali in which the gender is indicated either by certain change or by some sorts of marker are said to have morphological gender. A small set of Nepali kinship terms( nouns )such as काका kaka 'paternal uncle' takes -ी-i: and changes to feminine as काकी kaki: 'aunt' Another set of terms such as नाति nati 'grandson' changes to its feminine form as नातिनी natini: by taking suffix -नी-ni:

\begin{tabular}{|l|l|l|l|l|}
\hline Masculine & Gloss & Feminine & Gloss & $\begin{array}{l}\text { Gender } \\
\text { marker }\end{array}$ \\
\hline $\begin{array}{l}\text { काका } \\
\text { kaka }\end{array}$ & Uncle & काको \kaki & Aunt & /-i \\
\hline $\begin{array}{l}\text { नाति । } \\
\text { nati }\end{array}$ & Grandson & $\begin{array}{l}\text { नातिनी। } \\
\text { natini }\end{array}$ & $\begin{array}{l}\text { grand } \\
\text { daughter }\end{array}$ & /-ni \\
\hline Devar & $\begin{array}{l}\text { Brother } \\
\text { in law }\end{array}$ & Devarani & $\begin{array}{l}\text { Sister in } \\
\text { law }\end{array}$ & /-ni \\
\hline $\begin{array}{l}\text { छोरा } \\
\text { IChorā }\end{array}$ & Son & छोरी।Chori & Daughter & /-i \\
\hline भाई।Bhai & Brother & बहिनि।Bhoini & Sister & /ni \\
\hline
\end{tabular}

Table 20 -- Representing Morphological gender

In the above Table20 o-ending and non-o-ending terms in Nepali that inflect for feminine gender by various ways are demonstrated [4]). Another popular suffixes in nepali ${ }^{6}$ are

\footnotetext{
${ }^{4}$ http://en.wikipedia.org/wiki/Morphology

${ }^{5}$ Aronoff sample chapter What is morphology.pdf

${ }^{6} \mathrm{Nepal} \mathrm{Bhasa-Wikipedia,} \mathrm{the} \mathrm{free} \mathrm{encyclopedia.mht}$
} 
chaa and ju. "Chaa" is added to signify "junior" or "lesser". But when added to a name, it is used derogatorily. For example, kya'ah-chaa means nephew where "chaa" is being added to kya'ah(son). When added to name like Amit for "Amitt-chaa", it is being used derogatorily. The suffix "ju" is added to show respect. For example, "Baa-ju" means "fatherin-law" where "ju" is added to "Baa(father)". Unlike "chaa", "ju" is not added to a first/last name directly. Instead, an honorific term like "Bhaaju" is added for males and "Mayju" for females. Example, "Birat bhaaju" for a male name (Birat) and "Suja Mayju" for a female name (Suja).

Prefix - "Tap'ah" is added to denote "remote" or "distant" relative ('distance' in relationship irrespective of spatial extent). A distant (younger) brother (kija) becomes "tap'ahkija". "Tuh" is added to denote "higher". Father (baa)'s senior brother is referred to as "Tuh-baa".

In Nepali kinship terminology, as in the lexicon in general, biological gender can be emphasized or disambiguated with of the two gendered suffixes "Sosura" (EF) and "sasu" ( EM ) in Nepali. It may be observed the addition of "sosura" and "sasu" is not only used for distinguishing the sex of the kinsmen but also found attached to the kin terms. The 'sosura' suffix generally added with male and 'sasu' with female gender .For example Jethasosura(HeB) husband elder brother and jethisasu(HeBW) and both derived from the kinship term jetha(FeB). Some examples with their corresponding gender marker are given below:

\begin{tabular}{|c|c|}
\hline Noun(kinship term) & Suffix/gender marker \\
\hline Budhasosura & sosura $\langle$ male $>$ \\
\hline Budhisasu & sasu<female $>$ \\
\hline kanchhasosura & sosura <male $>$ \\
\hline Kanchhisasu & sasu<female> \\
\hline Jethasosura & sosura $\langle$ male $>$ \\
\hline Jethisasu & sasu<female $>$ \\
\hline Mamasosura & sosura <male $>$ \\
\hline Maijusasu & sasu<female $>$ \\
\hline Thulobabusosura & sosura <male $>$ \\
\hline Thuliamasasu & sasu<female> \\
\hline Sanobabusosura & sosura <male $>$ \\
\hline Saniamasasu & sasu<female $>$ \\
\hline phupajusosura & sosura <male $>$ \\
\hline Phupusasu & sasu<female> \\
\hline
\end{tabular}

Table 21-- Representing gender marker

Doubling, reduplicative, near reduplicative or mirror forms is a common and well-attested feature of kinship terminologies[7] in many of the world's languages, including Nepali. In reduplication, the reduplicate is most often repeated only once. However, in some languages, reduplication can occur more than once. The kinship term 'kaka' (father's younger brother) is a reduplication form of ' $\mathrm{ka}$.' And other examples are 'mama' (mother's brother),' didi'('elder sister) etc.
A word can either be in simple, complex, or compound. A simple word consists of a root or stem together with suffixes or prefixes. A compound term can be broken up into two or more independent terms. Same rule is applicable for Nepali Kinship terms. Some Nepali kinship term consists of one or more independent kinship terms. 'Mama' and 'sosura' are two independent kinship term in Nepali language. 'Mamasosura' also another kinship term in Nepali which is the combination of previous two kinship term Mama(MB) and sosura(EF). Some examples with their corresponding word form (simple $\&$ Compound) are given below:

Jethasosura(Compound)-- $\rightarrow$ Jetha(simple) +Sosura(simple)

Kanchhasosura(Compd) $\rightarrow$ Kanchha(simple) + Sosura(simple)

Kanchhisasu (Compound) $-\rightarrow$ Kanchhi(simple)+Sasu(simple)

In Nepali, there are two numbers and they are singular and Plural. For the plural of noun, generally it adds the suffix-haru to the end of a word.

\begin{tabular}{|c|c|}
\hline Nepali Singular & Nepali plural \\
\hline Bhai(yB) & Bhaiharu \\
\hline Daju(eB) & Dajuharu \\
\hline Didi(eZ) & Didiharu \\
\hline Chhora(S) & Chhoraharu \\
\hline
\end{tabular}

Table 22- Representing Number

Nepali kinship terms are usually closely linked to specific pronouns which in turn require specific verbal endings [6]. In other words, when addressing one's own father or someone of that age, one should use the kinship term Phupu and the pronoun tapai.

\begin{tabular}{|l|c|l|}
\hline $\begin{array}{c}\text { Noun (Kinship } \\
\text { term) }\end{array}$ & Pronoun: & \multicolumn{1}{|c|}{ Verbal ending: } \\
\hline $\begin{array}{l}\text { Phupu/ } \\
\text { Ama, dai, didî }\end{array}$ & Topai/Hajur & $\begin{array}{l}\text {-nuhuncha } \\
\text { (indicative present) } \\
\text {-nuhos (imperative) }\end{array}$ \\
\hline Bhai, Bahina & Timi & $\begin{array}{l}\text {-chau (indicative } \\
\text { present) } \\
\text {-au ; -a } \\
\text { (imperative) }\end{array}$ \\
\hline Babu, Nani & Timita & $\begin{array}{l}\text {-chau (indicative } \\
\text { present) }\end{array}$ \\
& & $\begin{array}{l}\text {-au ; -a } \\
\text { (imperative) }\end{array}$ \\
& & $\begin{array}{l}\text {-chas (indicative } \\
\text { present) } \\
\text { - (imperative }\end{array}$ \\
\hline
\end{tabular}

Table 22-Relation between Noun, pronoun \& verb of kinship term 
On the other hand, in a conversation with one's younger sister, one would use the term bahinî and most likely the personal pronoun timi. The table 22 above is a provisional attempt at categorizing these relationships.

\section{Conclusion:}

Kinship terms generally replace an individual's given name, both as a term of address and for reference. Moreover the metaphorical usage of kinship terms to non-kin is widely observed among the Nepali language. Formation of kinship terms in Nepali language and its morphology have been discussed in the paper. It is seen that the prefixes and suffixes play a major role in formation of the kinship terms in Nepali Language. Moreover for formation of kinship terms it follows some pattern or paradigm in Nepali language. This report can serve as a strong base document for Nepali WordNet[1] development in Nepali language.

\section{References}

[1] Alok chakraborty, Bipul Shyam Purkayastha, Arindam Roy (2010), Experiences in building the Nepali Wordnet, Proceedings of the 5th Global WordNet Conference, Mumbai.India.

[2] Anju Giri (2001): English and nepali kinship terms Journal NELTA, Vol 6,No 1.

[3] Arindam Roy,Sunita Sarkar,Bipul Syam Purkayastha,(2012): A Proposed Nepali Synset entry and extraction tool, Proceedings of the 6th Global WordNet Conference, Matsue, Japan
[4] Balaram prasain (2012): A computational analysis of Nepali morphology: A model for natural language processing.

[5] Ichchha Purna Rai (2010) : Bantawa kinship Terminology.

[6] Mark Turin (2001): Call me uncle: an outsider's experience of nepali kinship.278 CNAS journal, vol 28, no 2 .

[7] Mark Turin(2004) : 'Thangmi kinship terminology in comparative perspective', pp. 101-139 in Anju Saxena, ed., Himalayan Languages: Past and Present. Berlin Mouton.

[8] Prajwal Rupakheti, Laxmi Prasad Khatiwada Bal Krishna Bal (2006): Report on Nepali Computational Grammar.

[9] Shikhar kr. Sarma, Biswajit Brahma, Mane Bala Ramchiary(2010): Formation of kinship terms in Bodo language.

[10] Satarupa Dattamajumdar, Kinship Terminology in Lepcha (2010):The Buckingham Journal of Language and Linguistics Volume 3 pp 179-185.

[11] Shikhar Kr. Sarma, Utpal Saikia and Mayashree Mahanta:(2010): Kinship terms in Assmese Language.

[12] Sydney M.LAMP( 1965) New Series, Vol. 67, No. 5, Part 2: Formal Semantic Analysis (Oct., 1965), pp. 37-64 Kinship terminology and linguistic structure. 